\title{
A Critical Assessment of Seedling Production Using a Floating Agriculture System in Bangladesh's Southern Submerged Ecosystem
}

\section{Raziuddin', Md Mahmudul Hasan Khan ${ }^{2 *}$, Takia Tanzina Akhter Bhuiyan³ , Gazi Nazmul Hasan', Md Rashedul Islam4, HM Khairul Bashar $^{1}$ and Nur Alam Siddiqui ${ }^{5}$}

${ }^{1}$ OFRD, Bangladesh Agricultural Research Institute, Bangladesh

${ }^{2}$ Plant Breeding Division, Bangladesh Agricultural Research Institute, Bangladesh

${ }^{3}$ Sher-e-bangla Agricultural University, Dhaka, Bangladesh

${ }^{4}$ Horticulture Centre, Bangladesh Agricultural Research Institute, Bangladesh

${ }^{5}$ SSO, Bangladesh Institute of Research and Training on Applied Nutrition,

Bangladesh

*Corresponding Author: Md Mahmudul Hasan Khan, Plant Breeding Division,

Bangladesh Agricultural Research Institute, Bangladesh.
Received: June 18, 2021

Published: June 29, 2021

(C) All rights are reserved by Raziuddin., et al.

\begin{abstract}
Floating agriculture system has a wide impact on livelihood of submerged ecosystem of southern region of Bangladesh. Research and documentation based on seedlings production based floating agriculture system on its productivity, stability, adaptability, sustainability, and profitability in situ condition is inadequate. Therefore, an approach was made to construct an overview of seedlings production based floating agriculture system based on farmers field condition trial, so that biospheres' and edaphic ecology would be utilized with indigenous inputs, nature of floating bed would be justified, pesticide use can be rationalised, productivity and marketability would be understood. Therefore, the trial was conducted at waterlogged ecosystem of Bisharkandi union, Banaripara upazilla of Barishal district during Kharif - 1 season from late May to October, 2018 to evaluate the performance of four vegetables (bottle gourd, papaya, bombay morich and brinjal) on conventional floating beds at farmers level in three batches i) BARI lau 4 ii) papaya (local) + bombay morich iii) hybrid bottle gourd + brinjal (local) + Bombay morich. The unit floating bed size was $60 \mathrm{~m}$ long $\times$ $1.2 \mathrm{~m}$ wide $\times 1.2 \mathrm{~m}$ height. Papaya (local) provided the maximum number of seedlings (59.29). The maximum number of marketable seedlings was provided by the second batch (3095) and hence the maximum gross return (20920 Tk.). The maximum total dry matter was provided by the third batch seedlings production. Floating bed prepared by indigenously had submergence rate $1.05 \mathrm{~cm} /$ day found less stable which frequently needed re-establishment by bed materials. Insects and disease infestation occurred sporadically. Non-judicious pesticides use with higher residual retention by indigenous farmers causing water body contamination in a drastic way. The net return attained from the trial was 26,998 Tk./bed.
\end{abstract}

Keywords: Seedling's Production; Floating Agriculture; Submerged Ecosystem

\section{Introduction}

Bangladesh is recognized worldwide as vulnerable country to the impacts of climate change where agriculture is the most climate sensitive sector. The country annually and inter-annually experience floods, cyclones, droughts, riverbank erosions, salinity intrusions, tornados and other natural calamities that have adverse effect on agriculture, fishery, infrastructure, water and health [1,2]. Although mitigation and adaptation are two ways of tackling the impact of climate change; realizing its huge population, and as a largely rural, least developed [3] as well as to accommodate unavoidable climate change $[4,5]$ adaptation would be the priority option to restrained the adverse impacts of climate change. The southern, 
southwestern and the coastal areas of Bangladesh remain submerged for long periods every year, especially during the monsoon season. People in these areas have been coping with submerged/ flooded conditions for generations [6].

Floating agriculture is not a new practice in Bangladesh; it has traditional roots in practices dating back to the country's forbearers, although the scientific component is a recent addition. According to their needs, people in different parts of Bangladesh have adopted, modified and named this practice differently [6-9], such as baira, boor, dhap, gathua, gatoni, geto, kandi and vasoman chash and floating agriculture; all these names represent this same traditional cultivation practice that can be scientifically referred to as hydroponics. The livelihood of the people in this area mainly depends on agriculture and they have no alternative sources of income generation. In these situations, the local farmers have adopted an innovative method of crop production technology namely, "floating agriculture" (locally known as "vasoman/dhap" chash) to cope with the flooded and submerged conditions. Dhap cultivation is found in remote, waterlogged villages of Barishal, Pirojpur and Gopalgonj districts of Bangladesh, but is not common elsewhere in the country. It was also observed that the floating agriculture is a suitable adaptation option in considering the environmental as well as social aspects under submerged ecosystem. Through this approach, farmers generally raise the seedlings of local cultivars of vegetable/spice crops. In addition to this, the area under floating cultivation is up to 10 times more productive than traditionally farmed land [10] and no additional chemical fertilizers or manure is required. When the crops have been harvested and floating rafts are no longer required, they can be used as organic fertilizers in the fields or incorporated into the following years floating beds as a fertilizer [6,11]. Therefore, productivity, nature and stability of floating bed, profitability and pesticide use of seedlings production based floating agriculture system in farmers field condition needed to be explored. Therefore, a trial was conducted considering the following objectives: To evaluate the productivity and profitability of seedlings production based floating agriculture system in farmer's field condition; to measure the nature and stability of floating bed in farmers field condition.

\section{Materials and Methods}

Climate and water body of trial site:

The geographical location of the trial site was under the sub-tropical climate, characterized by three distinct seasons, winter season from November to February and the pre-monsoon period or hot season from March to April and monsoon period from May to
October. The experiment was conducted at waterlogged ecosystem of Bisharkandi union, Banaripara upazilla of Barishal (22 $42^{\prime} 57.2^{\prime \prime}$ N, 900.' 17.5” E) (Figure 1). Generally, at Bisharkandi union, Banaripara upazilla of Barishal waterlogging period starts from late May and stays up to mid-October. Water coming from the adjacent rivers and canal on farmer's field is tidal. This ebbs and flow tide make the ecosystem unique for floating agriculture practices. Water body dissolved oxygen level is normal and slightly saline.
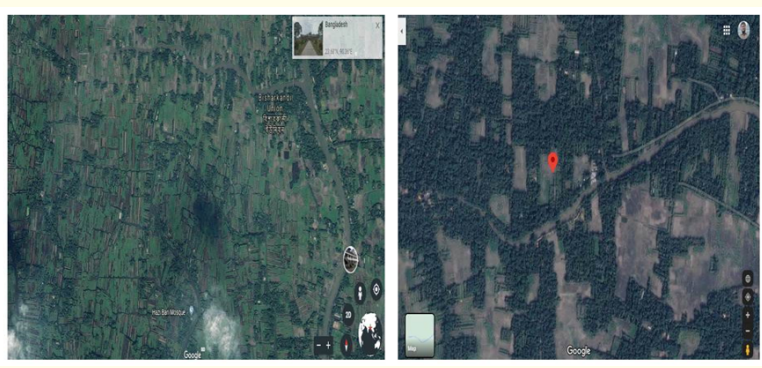

Figure 1: Location of the study area on google maps.

\section{Characteristics of floating agricultural practices}

Floating seedlings productions are age-old practice of crop cultivation in the Southern floodplains of Bangladesh (Barishal and Pirojpur districts). Floating garden agricultural practices (locally known as Dhap) for growing vegetables and spices prevail in the wetlands of the south-central coastal districts of Bangladesh. With the use of abundantly available water hyacinth (Eichhornia crassipes) and other aquatic weeds, local communities have developed a technique to construct reasonably sized floating platforms or raft on which vegetables and other crops can be cultivated. The unique hydroponics production system was developed in the hands of the locals by using their traditional knowledge for agricultural practice and livelihood. The production system is the major livelihood option for about $60-90 \%$ of the locals. Bio-diverse vegetables and spices crops are grown sustainably over the years on floating substrata made mainly of water hyacinth and other minor aquatic weeds on flooded water. The land with the water is used for production of fish in the open water and crops on the floating beds. Thus, ensures a sustainable utilization of agro biodiversity, natural resources and multiple use of the land.

Farmers of the area have been practicing the method mainly for two reasons. First, during monsoons, when most of the land is flooded, floating agriculture is the only alternative method of 
cultivation. In the monsoon (mainly during June-August), farmers cultivate ladies finger (okra), cucumber, snake gourds etc. on the floating system. After the monsoon, farmers use this for cultivating spinach, aurum, spices and several other vegetables. During the monsoon, farmers use small boats to manage the floating agricultural land. Second during the winter season, farmers carry the floating bed to higher grounds where they break it and mix it with the soil to enrich the soil. The primary goal of the practice is to promote sustainable local natural resource management (submerged regions) using floating agricultural practices. Another goal is to deal with the effects of climate change.

\section{Trial design and layout}

During monsoon period, farmers produced three/four batches of seedlings. There is a wide range of vegetable seedlings production in the region. But for the trial, seedling performances of four vegetables/spices crops (bottle gourd, papaya, brinjal and bombay chili) were evaluated on conventional water hyacinth made floating bed at farmers level (Table 1).

\begin{tabular}{|l|c|c|}
\hline \multicolumn{1}{|c|}{ Batch } & Crops & Variety \\
\hline One & Bottle gourd & BARI Lau-4 (Bottle gourd) \\
\hline Two & $\begin{array}{c}\text { Papaya + Bombay } \\
\text { Chili }\end{array}$ & $\begin{array}{c}\text { Local (papaya), Local } \\
\text { (Bombay Chili) }\end{array}$ \\
\hline Three & $\begin{array}{c}\text { Bottle gourd + } \\
\text { Brinjal + Bombay } \\
\text { Chili }\end{array}$ & $\begin{array}{c}\text { Hybrid (Bottle gourd), local } \\
\text { (brinjal), Local (Bombay } \\
\text { Chili) }\end{array}$ \\
\hline
\end{tabular}

Table 1: Batch number, crops and variety used in the trial.

\section{Floating bed size and material}

The unit floating bed size was $60 \mathrm{~m}$ long $\times 1.2 \mathrm{~m}$ wide $\times 1.2$ $\mathrm{m}$ height. The floating bed was purchased from nearby villages where these traditional beds were produced at commercial basis and brought to the site through the canals. Floating bed (Figure 2) is generally composed of decomposed water hyacinth, topapana (Pistia stratiotes L.), indigenous floating algae and a type of water grass [Hygroryza aristata (Retz.) Nees ex Wight and Arn..] to bind the seedling balls. Sometimes, coconut dust is used to germinate seedlings in farmer's field condition. Floating bed materials differs from location to location, depending on the availability.

\section{Seedlings production method}

At first the sprouted seeds (especially large seeds e.g., bottle gourd, sweet gourd etc.) of these crops were placed in small ball
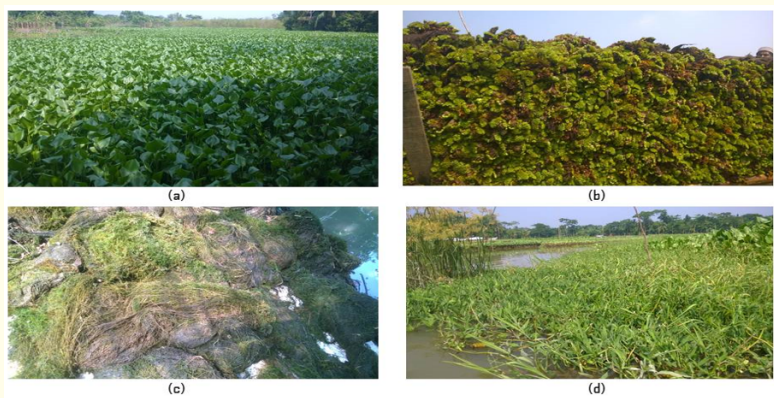

Figure 2: Water hyacinth (Eichornia crassipes Mart.) (a), topapana (Pistia stratiotes $L$ ) (b), floating algae (c) and dulali lata (Hygroryza aristate (Retz.) Nees ex Wight \& Arn.) (d) used as material for floating bed preparation.

(prepared with decomposed water hyacinth, topapana, dulali lata and floating algae). These ball forming materials varies from place to place according to its availability. Moreover, small seeded vegetables like brinjal, bombay morich seeds were germinated in separately prepared floating seedbed made with water hyacinth and coconut dust. The germinated young seedlings of these vegetables were then transferred to small balls/dola/tema (Figure 3). After that, the small balls/dola/tema was replaced to the floating beds and spacing was maintained accordingly considering the foliar coverage of crops. After the arrangement of the tiny balls on the floating bed, intercultural activities such as the placement of topapana (pistia stratiotes L) and dulalilata, a water grass, were performed to maintain and rejuvenate the floating bed from decomposition, which prevented in rapid submergence. Pesticides (Table 3) and fertilizers (mainly urea) were applied at regular interval.

\section{Data collection}

Data were collected on different parameters such as number of? seedlings $/ \mathrm{m}^{2}$, plant height, root length, dry root and shoot weight, total dry matter, number of marketable/unmarketable seedlings per bed and days to harvest of vegetables/spices seedlings, floating bed height at ten days interval, list of pesticides used and their spray interval at farmers level, observable diseases, cost and return analysis.

\section{Results and Discussion}

Data collected from the trial in farmer's field condition are represented in table 2 . From table 1 it can be observed that, seedlings 

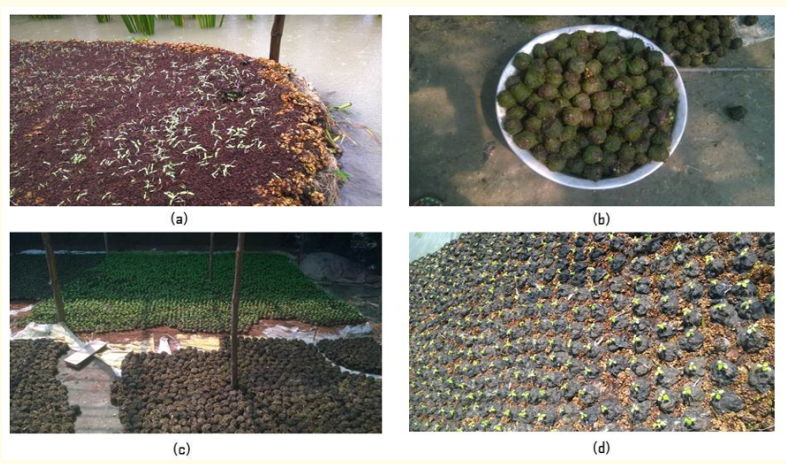

Figure 3: Seedlings germinated on coco-dust (a), seedlings germination on tema/ball made from water hyacinth (b), balls for germination of seedlings kept in a shady place (c) and germinated seedlings ball placed in the floating bed (d).

per $\mathrm{m}^{2}$ of vegetables and spices seedlings depend on the foliage coverage of the crops until the harvestable stage. Bottle gourd seedlings require larger space than papaya, brinjal and Bombay chili seedlings (Figure 4). At first batch, number of bottle gourd seedlin- gs was 25.16 per $\mathrm{m}^{2}$, at third batch 30.16. Papaya seedlings maintained the higher plant population at second batch (59.29). At second batch, plant population $/ \mathrm{m}^{2}$ of Bombay chili was 53.4. At third batch, plant population $/ \mathrm{m}^{2}$ of Bombay chili was higher compared to second batch (58), hybrid bottle gourd (30.16) and local brinjal (49.9) also maintained a better seedlings population $/ \mathrm{m}^{2}$.

The shoot length for first batch bottle gourd seedlings was 16.8 $\mathrm{cm}$ whereas the root length was found $22.95 \mathrm{~cm}$. Floating bed being organic in nature, first batch bottle gourd seedlings got advantage of better root proliferation and establishment. In second batch, Bombay chili seedling exhibited the highest shoot length $(22.9 \mathrm{~cm})$ and root length $(9.8 \mathrm{~cm})$. At third batch, Bombay chili seedlings demonstrated higher shoot length $(26.5 \mathrm{~cm})$ but higher root length can be observed from hybrid bottle gourd $(21.40 \mathrm{~cm})$. The highest average total dry matter content/plant can be observed from first batch bottle gourd seedlings (17.02 g/plant). The lowest dry matter content can be observed from papaya seedlings at second batch (1.6 g/plant).

Shoot and root length of vegetables/spices depended on the harvesting time of the seedlings. At first batch, farmers wanted to

\begin{tabular}{|c|c|c|c|c|c|c|}
\hline Batch & Crops & $\begin{array}{l}\text { Shoot } \\
\text { length } \\
\text { (cm) }\end{array}$ & $\begin{array}{l}\text { Root length } \\
\text { (cm) }\end{array}$ & $\begin{array}{c}\text { Dry root } \\
\text { weight/plant } \\
\text { (gm) }\end{array}$ & $\begin{array}{c}\text { Dry shoot } \\
\text { weight/plant } \\
\text { (gm) }\end{array}$ & $\begin{array}{c}\text { Total dry } \\
\text { matter/ } \\
\text { plant (g) }\end{array}$ \\
\hline $1^{\text {st }}$ & BARI Lau-4 & 16.8 & 22.95 & 1.68 & 15.34 & 17.02 \\
\hline \multirow{2}{*}{$2^{\text {nd }}$} & Papaya (local) & 19.7 & 3.70 & 0.26 & 1.84 & 1.6 \\
\hline & Bombay Chili & 22.9 & 9.80 & 0.36 & 7.308 & 7.668 \\
\hline \multirow{3}{*}{$3^{\text {rd }}$} & Bottle gourd (Hybrid) & 24.4 & 21.40 & 1.89 & 15.11 & 14.61 \\
\hline & Brinjal (Local) & 17.8 & 8.55 & 0.77 & 12 & 12.77 \\
\hline & Bombay Chili & 26.5 & 12.34 & 0.78 & 10.5 & 11.1 \\
\hline Batch & Crops & $\begin{array}{l}\text { Seedlings } \\
\mathbf{m}^{-2} \text { (no.) }\end{array}$ & $\begin{array}{l}\text { No. of marketable } \\
\text { seedlings/Bed }\end{array}$ & \multicolumn{2}{|c|}{$\begin{array}{c}\text { No. of unmarketable seedlings/ } \\
\text { Bed }\end{array}$} & $\begin{array}{l}\text { Days to } \\
\text { Harvest }\end{array}$ \\
\hline $1^{\text {st }}$ & BARI Lau-4 & 25.16 & 715 & \multicolumn{2}{|c|}{85} & $20-22$ \\
\hline \multirow{2}{*}{$2^{\text {nd }}$} & Papaya (local) & 59.29 & 1920 & \multicolumn{2}{|c|}{211} & $25-35$ \\
\hline & Bombay Chili & 53.4 & 1175 & \multicolumn{2}{|c|}{130} & $25-35$ \\
\hline \multirow{3}{*}{$3^{\text {rd }}$} & Bottle gourd (Hybrid) & 30.16 & 225 & \multicolumn{2}{|c|}{38} & $30-40$ \\
\hline & Brinjal (Local) & 49.9 & 812 & \multicolumn{2}{|c|}{72} & $40-45$ \\
\hline & Bombay Chili & 58 & 746 & \multicolumn{2}{|c|}{76} & $40-45$ \\
\hline
\end{tabular}

Table 2: Performance of different vegetables/spices seedlings on conventional floating bed at farmer's level. 
market the produce as early as possible and maintained a short turnover period. But at third batch, farmers decided to keep the produce longer time as the seedlings demand falls. So, the seedlings at third batch exhibited the highest shoot and root length and total dry matter (Table 2) compared to others.

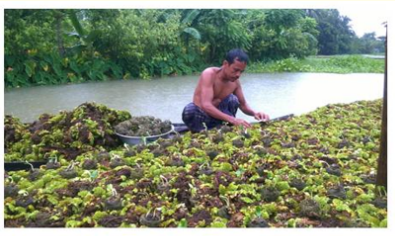

(a)

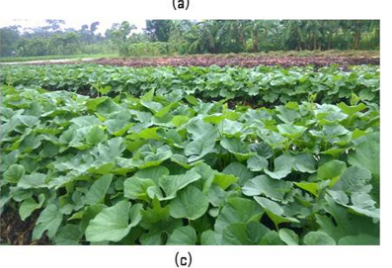

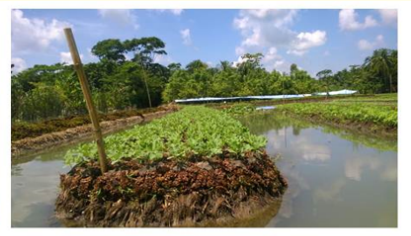

(b)

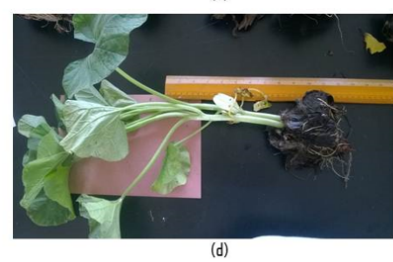

Figure 4: Placing of bottle gourd seedlings ball in floating bed (a), growing stages of bottle gourd seedlings on floating bed (b, c) and data collection of bottle gourd seedlings.

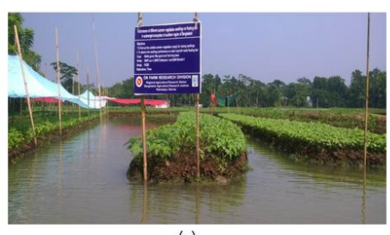

(a)

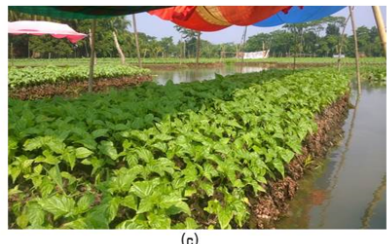

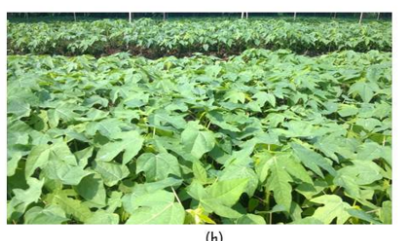

(b)

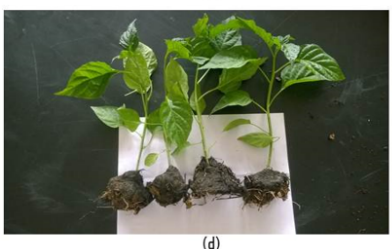

Figure 5: Established floating bed of papaya and Bombay chili seedlings on floating bed $(a, b, c)$ and data collection of Bombay chili seedlings (d).

The highest marketable seedlings were attained from Bombay chili (1921seedlings) (Figure 5) from second and third batches and papaya (1920 seedlings) from $2^{\text {nd }}$ batch (Table 2). Considering the batches, second batch has provided the maximum number of marketable seedlings (3095). Days to harvest of vegetables/spices seedlings largely depend on the market demand and price, favorable weather conditions etc. Farmers had to sell the seedlings at local floating market or to the local small entrepreneurs. From table 2, it can be observed that, seedlings at third batch were harvested after long period (40 - 45 days).

\section{Estimation of floating bed stability}

Floating bed stability was measured by estimation of submergence rate. Decomposition of floating bed materials depends on the proportion of floating bed materials, climatic condition, quality of water body etc. During the cultivation period in monsoon, farmers reconstruct their floating bed several times. Estimation of submergence rate was measured by determining the floating bed mainframe height at 10 days interval.

\section{Submergence rate $=\frac{\text { Initial height of floating bed mainframe }- \text { measured reading }}{\text { Days interval }}$}

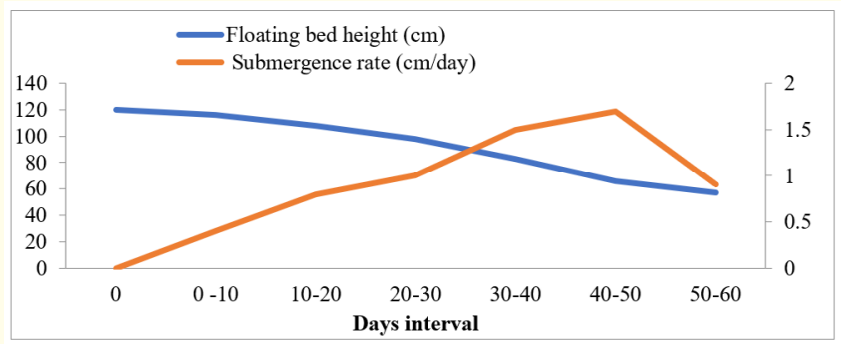

Figure 6: Floating bed height and submergence rate of conventional floating bed in farmers field conditions.

The figure 6 denoted that, floating bed height reduction was related with organic matter compaction, volume of nitrogenous fertilizer application, decomposition and water body quality. From figure, it can be observed that decomposition of floating bed materials was peak at 40-50 days after culturing. So that, submergence rate was higher 40-50 days after culturing. From the data, average submergence rate was found $1.05 \mathrm{~cm} /$ day. Various diseases and insect infestation affected on the marketability of seedlings. List of observable diseases were listed in table 4 and the use of pesticides listed in table 3. 


\begin{tabular}{|l|c|c|}
\hline \multicolumn{1}{|c|}{ Pesticides } & Active ingredient & $\begin{array}{c}\text { Spray } \\
\text { Interval (days) }\end{array}$ \\
\hline Cindazim & Carbendazim & 10 \\
\hline Zimper & Carbendazim & 10 \\
\hline Furadan & Carbofuran & 10 \\
\hline Antracol & Dithiocarbamate & $6-7$ \\
\hline Companion & Mancozeb +Carben- & - \\
\hline Ridomil Gold & Mancozeb +Metalaxyl & - \\
\hline Andrin & Chlorpyrifos & $5-6$ \\
\hline Nitro & Chlorpyrifos & $8-9$ \\
\hline Tido & Imidachloprid & $7-8$ \\
\hline Acimix & $\begin{array}{c}\text { Chlorpyrifos + } \\
\text { Cypermethrin }\end{array}$ & - \\
\hline
\end{tabular}

\begin{tabular}{|l|c|}
\hline \multicolumn{1}{|c|}{ Diseases } & Crop/s \\
\hline Alternaria leaf blight & Bottle gourd \\
\hline Damping off & Papaya, Bombay chili, \\
& Brinjal \\
\hline Root rot & Papaya \\
\hline Wilt & Bottle gourd, Brinjal \\
\hline
\end{tabular}

Table 4: List of diseases prevailed in seedlings production of floating agriculture.

Table 3: List of pesticides, their active ingredients and spray interval used in floating agriculture at Bisharkandi, Banaripara, Barishal.

\section{Cost and return analysis}

Cost and return analysis of conventional floating agriculture system is represented in table 5 . From table 5 , it can be observed

that, input cost of the single floating bed was 13,500 Tk. except the labor cost as farmers worked themselves. This cost includes the material cost (bed and bed materials, seeds, fertilizer and pesticides) and non-material cost (ball preparation labor). The minimum gross return can be recorded from first batch of seedlings production (5720 Tk.) whereas the maximum gross return can be recorded from second batch seedlings production (20920 Tk.). The third batch seedlings production has given the gross return of $13858 \mathrm{Tk}$. Vegetables/spices seedlings price varied widely during the cropping season. Considering the average price of the seedlings, gross return was $40,490 \mathrm{Tk}$. whereas the net return was 26,998 Tk (Table 5).

\begin{tabular}{|l|c|c|c|c|c|c|}
\hline Items/Materials & Cost (in Tk.) & Crops & $\begin{array}{c}\text { Seedlings } \\
\text { No. }\end{array}$ & $\begin{array}{c}\text { Rate (in } \\
\text { Tk.) }\end{array}$ & $\begin{array}{c}\text { Gross return } \\
\text { (in Tk.) }\end{array}$ & $\begin{array}{c}\text { Net Return } \\
\text { (in Tk.) }\end{array}$ \\
\hline Floating bed & 4200 & \multicolumn{4}{|c|}{$1^{\text {st } \text { batch }}$} \\
\hline Topapana & 2000 & Bottle gourd & 715 & 8 & 5720 \\
\hline Dulali lata & 1500 & \multicolumn{4}{|c|}{$2^{\text {nd } \text { batch }}$} \\
\hline Coconut dust & 300 & Bombay morich & 1175 & 8 & 9400 \\
\hline Floating algae & 300 & Papaya & 1920 & 6 & 11520 \\
\hline Seed & 2000 & \multicolumn{3}{|c|}{2} \\
\hline Ball preparation (Labour) & 1200 & Bottle gourd & 225 & 8 & 1800 \\
\hline Fertilizers & 1000 & Bombay morich & 746 & 8 & 5968 \\
\hline Pesticides & 1000 & Brinjal & 812 & 7.5 & 6090 \\
\hline Total & 13,500 & & & & 40,490 \\
\hline
\end{tabular}

Table 5: Cost and return analysis of seedlings production on floating bed at Bisharkandi, Banaripara, Barishal.

\section{Farmer's reaction}

Farmers were willing to cultivate HYV vegetables crops instead of hybrid. They preferred the performance of BARI Bottle gourd-4 seedlings on floating bed. They also opined that, during the early monsoon they required vast amount of quality vegetables seedlings. As for example, it needs 700-800 gm. bottle gourd seeds to produce single batch seedlings on floating bed. So, they procured 
farmers level vegetables seeds at low price whereas the quality is not guaranteed. They also expressed their dissatisfaction about the instability of seedlings market price.

\section{Conclusion and Recommendations}

Floating agriculture in waterlogged ecosystem of southern region has a huge impact to the livelihood of marginal farmers. Scarcity of improved HYV seed is a great hindrance to its practice. Moreover, non-judicious use of pesticides is a major concern to surface water pollution where use and expansion of bio pesticides is vastly needed. More research should be conducted on mitigation of water pollutant and pesticide residue as early as possible. Moreover, more stable floating bed technology should be derived from indigenous materials. Apart from the trial, there are diversified vegetables/spices crops traditionally practiced for seedlings raising or crop production. Therefore, more trials and extension should be conducted to improve the practice.

\section{Acknowledgement}

Authors are grateful to Bangladesh Agricultural Research Institute (BARI), Bangladesh for technical support. Special gratitude goes to Dr. Md Abdul Wohab, Director General, BARI, Bangladesh for his direct supervision.

\section{Competing Interests}

Authors have declared that no competing interests exist.

\section{Bibliography}

1. ADPC and BCAS (Asian Disaster Preparedness Centre and Bangladesh Centre for Advance Studies). "Draft Disaster Management Information Link Report". Ministry of Food and Disaster Management, Government of Peoples Republic of Bangladesh, Dhaka, Bangladesh (2008).

2. Sutradhar LC., et al. "A Review of Good Adaptation Practices on Climate Change in Bangladesh". International Conference on Water and Flood Management (ICWFM-2015) (2015): 607614.

3. Rahman M. "Framing Ecosystem-based Adaptation to Climate Change: Applicability in the Coast of Bangladesh, Dhaka, Bangladesh". IUCN, x+43 (2014).

4. IPCC. Synthesis Report. Contribution of Working Groups I, II and III to the Third Assessment Report of the Intergovern- mental Panel on Climate Change, R. T. Watson and the Core Writing Team (eds.). Cambridge University Press, Cambridge, England (2001): 365.

5. Ayers J and S Huq. "The Value of Linking Mitigation and Adaptation: A Case Study of Bangladesh". Environmental Management 43 (2009): 753-764.

6. APEIS and RIPSO. "Floating Agriculture in the flood-prone or submerged areas in Bangladesh (Southern regions of Bangladesh)". Bangladesh: APEIS and RIPSO (2004).

7. Islam $\mathrm{T}$ and $\mathrm{P}$ Atkins. "Indigenous Floating Cultivation: A Sustainable Agricultural Practice in the Wetlands of Bangladesh". Development in Practice 40.1 (2007): 130-136.

8. Irfanullah HM., et al. "Introduction of Floating Gardening in the North - eastern Wetlands of Bangladesh for Nutritional Security and Sustainable Livelihood". Renewable Agriculture and Food Systems 23.2 (2007): 89-96.

9. Islam MA., et al. "Perception of haor farmers about the innovative features of floating farming". International Journal of Natural and Social Sciences 2.4 (2015): 52-58.

10. Haq AH., et al. "Cultivating Wetlands in Bangladesh". India: LEISA (2004).

11. Saha SK. "Soilless Cultivation for Landless People: An Alternative Livelihood Practice through Indigenous Hydroponic Agriculture in Flood-prone Bangladesh". Ritsumeikan Asia Pacific University (2004): 139-152.

\section{Volume 5 Issue 7 July 2021 \\ (C) All rights are reserved by Raziuddin., et al.}

